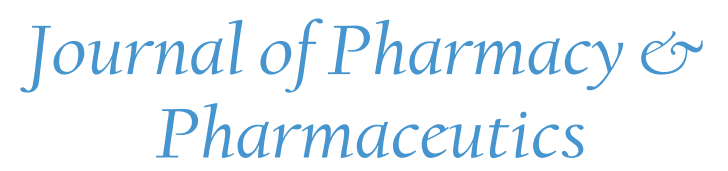

\title{
Antimalarial, Non Alkaloidal Molecules from Preliminary Elucidation of Nauclea Diderechi Extract
}

\author{
Muluh Emmanuel Khan*
}

Department of Chemistry, School of Science, University of Agriculture, Nigeria

*Corresponding author: Muluh Emmanuel Khan, Department of Chemistry, School of Science, University of Agriculture, P M B. 2373, Makurdi, Benue state, Nigeria, Tel: +2347031667488; Email: emamulu@yahoo.com

\begin{abstract}
The work investigated pharmacologically useful classes of compounds, from the petroleum ether fraction of the stem bark of Nauclea diderichii. From the bioassay, most of the microbes showed sensitivity except for Streptococcus pyrogenes, Proteus vulgaris, Pseudomonas aeruginosa and the fungus Candida stellatoidea, where the extracts were non -active. Petroleum ether extract was below detectable limits (BDL) in methicillin resistant Staphylococcus aureus, Streptococcus pyrogenes, Corynebacterium ulcereas, Proteus mirabilis, Proteus vulgaris, Pseudomonas aeruginosa and the fungi, Candida albucans, Candida stellatoidea and Candida tropical. Chloroform extract had the highest activity, followed by the ethyl acetate, then the methanol and lastly the petroleum ether. Minimum inhibitory concentration (MIC) was $1.25 \mathrm{mg} / \mathrm{mL}$ on the average. MBC was $2.25 \mathrm{mg} / \mathrm{mL}$ and MFC $5.00 \mathrm{mg} / \mathrm{ml}$. Anti-malaria activity showed the $\mathrm{LD}_{50}$ of the acute toxicity as $\geq 3800 \mathrm{mg} \mathrm{kg}^{-1}$ body weight. The suppressive test, curative effect, prophylactic effect and the survival periods were highly encouraging. Three compounds were isolated from the preliminary pet. Ether fraction of Nauclea diderichii and identified by infrared (IR), ultraviolet (UV) and gas/liquid chromatography -mass spectroscopy (GC/LC-MS), analyses as Hexadecanoic acid,15-methyl-, methyl-ester,7- Tetradecenal and 9- and 10- octadecenoic acid, methyl ester. These findings were in consonance with literature of plants and lent credence for the use of the stem bark of Nauclea diderichii as a potential natural drug source for treatment of some ailments in Adamawa State of northeastern Nigeria and beyond.
\end{abstract}

Received date: November 23, 2015

Accepted date: April 22, 2016

Published date: April 28, 2016

Citation: Khan, M.E. Antimalarial, Non Alkaloidal Molecules from Preliminary Elucidation of Nauclea Diderechi Extract (2016) J Pharm Pharmaceutics 3(1): 54- 60.

DOI: $10.15436 / 2377-1313.16 .012$

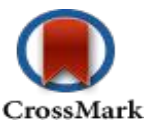

Keywords: Nauclea diderichii; Bioassay; Pharmacology; Preliminary-elucidation, Microbes, Anti- Malaria; Chromatography

\section{Introduction}

Phytomedicine has been found to be active against a wide variety of micro-organisms and has shown great promise in the treatment of many intractable diseases including opportunistic AIDS infections. Most of them have been investigated for their chemical components and some of the isolated compounds have been shown to posse diverse and interesting biological activities ${ }^{[1,2]}$.

In Mubi north and south LGAs of Adamawa State Northeastern Nigeria, malaria, diarrhea and dysentery are health challenges ${ }^{[3,4]}$ and is believed Nauclea diderichii possesses medicinal properties effective in their management since decoctions of this plant are used for their cure like the rinds of Punica granatum ${ }^{[5,6]}$.

Nauclea diderichii (De Wild \& Dur) Meril (Rubiaceae). (Commercial name: bilinga) Common name; African peach, is reputed for its numerous medicinal uses as a tonic and fever medicine, chewing stick, toothaches; dental caries, septic mouth, malaria, 
diarrhea and dysentery cure[ ${ }^{[7]}$.

Scientists are still to justify the claim that children suffer from severe dysentery/diarrhea during teething. But it could be inferred that this is a time when the children are exposed to lots of contaminated things as they crawl around and imbibe virtually everything. In Mubi LGAs, North Eastern Nigeria, the stem bark of bilinga are used (oral decoction), for the treatment of malaria and dysentery /diarrhea both in children and adults (Per comm.).

\section{Subject}

This paper makes an attempt at the preliminary elucidation of some of the structures found in this indigenous medicinal plant, their potentials against some disease causative micro-organisms, plasmodium berghei berghei Nk65, bacteria and fungi, due to antibiotic resistance in nosocomial and community acquired infections, thus viewing Nauclea diderichii as a potential source for phytomedicine development.

\section{Materials and Methods}

\section{Collection of plant materials:}

Fresh samples of the stem bark of the African peach were collected in Michika Adamawa State and were identified in the Biological Sciences Department of Adamawa State University Mubi. The FHI number is 0194 and a specimen of the plant was deposited in the herbarium. The sample $(1.4 \mathrm{~kg})$ was air dried in the laboratory before pounding to a fine powder using pestle and mortar to about 70 mesh sizes and then stored in a dry container.

\section{Extraction}

$400 \mathrm{~g}$ of the powdered stem bark was accurately weighed and percolated with 10L of distilled ethanol for $72 \mathrm{hrs}$ to get the crude extract. After which there was decantation, filtration, and concentration using rotary evaporator $(\mathrm{R} 110)$ at $35^{\circ} \mathrm{C}$. It was later macerated with different solvents of increasing polarities starting with petroleum ether, chloroform, ethylacetate and methanol using serial extraction to have their corresponding fractions.

\section{Anti-bacterial Profile (Susceptibility Test)}

The antibacterial screening was carried out using the agar diffusion method, (Lino and Deogracios, 2006) with slight modifications. Overnight culture of the various bacteria in blood agar and the fungi in Sabouraud dextrose agar slant media were sterilized to produce inoculums size of $10^{6} \mathrm{cfu} / \mathrm{mL}$. The medium was seeded with standard inoculums $(0.1 \mathrm{~mL})$ of the micro-organism (mc-for land 0.5). The inoculums were sprayed evenly by the use of sterile swab over the surface of the medium; the seeded plates were allowed to dry at $37^{\circ} \mathrm{C}$ for 30 mins inside incubator. A standard cork borer $(6 \mathrm{~mm})$ was used to cut a well at the centre of each seeded medium used and the solution of the crude extracts $(10 \mathrm{mg} / \mathrm{mL})$ was then introduced into each hole on the surface of the medium. In one medium was introduced dimethylsulphoxide (DMSO) $(0.1 \mathrm{~mL})$ to serve as negative control and sparfloxacin $(20 \mu \mathrm{g} / \mathrm{mL})$ for the bacteria and fluconazole $(50 \mu \mathrm{g} / \mathrm{mL})$ for the fungi to serve as positive controls respectively. The medium was incubated at $37^{\circ} \mathrm{C}$ for 24 hours for $2-7$ days for the bacteria and fungi respectively. The plates were then observed for zones of inhibitions which were measured with a transparent ruler and results recorded.

\section{Determination of Minimum Inhibitory Concentration (MIC)}

MIC was determined using broth dilution method ${ }^{[8]}$, modified by ${ }^{[9]}$ Usman, Abdulrahman, and Ladan, 2007). Two fold serial dilutions of the crude extract were made to obtain concentrations of $5,2.5,1.25,0.625,0.3125 \mathrm{mg} / \mathrm{mL}$ ) suspension of standard inoculum of each organism was inoculated to the different concentrations. The test tubes were then incubated at $37^{\circ} \mathrm{C}$ for $24 \mathrm{~h}$ after which they were observed for growth. Inhibition of growth was indicated by a clear solution. The MIC was defined as the lowest concentration of the extract inhibiting the visible growth of each microorganism.

\section{Determination of Minimum Bactericidal Concentration / Minimum Fungicidal Concentration (MBC / MFC)}

The contents of the above MIC tubes and the preceding tubes in the serial dilution were sub-cultured into appropriately labeled nutrient agar plates by dipping a sterile wire loop into each test tube and streaking the surface of the labeled nutrient agar plates. The plates were then incubated at $37^{\circ} \mathrm{C}$ for $24 \mathrm{hrs}$ after which they were observed for growth of colony. The lowest concentration of the subculture with no growth for both bacteria and fungi were considered as minimum bactericidal/fungicidal concentrations $^{[8,9]}$.

\section{Anti-Malarial Studies}

An antimicrobial study was carried out in two phases using modified ${ }^{[10]}$ Lorke (1983). The oral median lethal dose $\left(\operatorname{LD}_{50}\right)$ was calculated using Plasmodium berghei berghei NK 65 parasites ${ }^{[1-13]}$.

The extracts caused a significant $(\mathrm{P}<0.05)$ chemo-suppression dose dependent reduction in parasitaemia levels in the extracts treated groups of Plasmodium berghei berghei NK 65 malaria parasite with a similar reduction in the chloroquine treated group (positive control). The results indicated that the stem bark possessed blood schizontcidal activity as evident from the chemo-suppression obtained during the four day early infection test and the 30 days curative / established infection comparable to the standard drug chloroquine, $5 \mathrm{mg} / \mathrm{kg} /$ day ${ }^{[14,15,16]}$. 


\section{Spectroscopic Measurement and component identification}

Continuous purification of the petroleum ether fraction led to the isolation of samples (H-2, structure 4), (H-3 structure7), \& (H-1 structure 6), colourless and oily in nature. These were chromatographed several times and sent for GC-MS analysis using Agilent 1100 Series Liquid Chromatography (LC/MSD Trap - VL Model) coupled to 3207 Mass Selective Detector (MSD), in DMSO as solvent in Natural Product Research Laboratory School of Chemistry University of Kwazulu - Natal West-Ville Campus, Durban, 4000, South Africa and the most prominent were:-

- structure 4, intensity of 5.500 , column oven temperature of $60^{\circ} \mathrm{C}$ injection temperature $250^{\circ} \mathrm{C}$ at retention time of 27.7 minutes, - structure 7, intensity of 6.500 , column temperature of $60^{\circ} \mathrm{C}$ injection temperature $250^{\circ} \mathrm{C}$ at retention time of 29.2 minutes, and, -structure 6 with intensities of 7.552 , with column oven temperature of $60^{\circ} \mathrm{C}$, injection temperature of $250^{\circ} \mathrm{C}$ at the retention time of 28.9 minutes, respectively.

\section{Discussion}

Pharmacologically useful classes of compounds, from the ethanol extract of the stem bark of Nauclea diderichii included, tannins, saponnins, terpenoids, glycosides, sterols, alkaloids, carbohydrates, flavovoids and phenols. Resins and phlobatannins were below detectable levels. From (Table 1), the study also confirmed that the stem bark had antibacterial activity against gram positive and negative bacteria and antifungal activity (Iwu 1993). It was most effective against Corynebacterium ulcereas, Staphylococcus aureus., Bacillus sublilis, Escherichia coli , Salmonella typhi, klebsiella pneumonia and the fungus Candida tropicalis ${ }^{[17]}$.

Table 1: Zone of inhibitions; Petroleum ether, Chloroform, ethyl acetate and methanol extracts of the stem bark of N. diderichii on some fourteen micro-organisms.

\begin{tabular}{|l|c|c|c|c|c|c|c|}
\hline \multirow{2}{*}{ Micro-organisms } & \multicolumn{9}{|c|}{ Zones of inhibition (mm) } \\
\cline { 2 - 8 } & Pet. Ether & Chloro. & Ethyl Act. & Methanol & Sparflox & .Flocona & DMSO \\
\hline Methicillin R.S.A & 00 & 25 & 00 & 21 & 33 & 00 & 00 \\
\hline Staphylococcus aureus & 15 & 27 & 21 & 22 & 35 & 00 & 00 \\
\hline Streptococcus pyrogenes & 00 & 00 & 00 & 00 & 32 & 00 & 00 \\
\hline Bacillus sublilis & 14 & 26 & 20 & 23 & 40 & 00 & 00 \\
\hline Corynebacterium ulcereas & 00 & 24 & 20 & 21 & 28 & 00 & 00 \\
\hline Escherichia coli & 17 & 27 & 21 & 22 & 30 & 00 & 00 \\
\hline Proteus mirabilis & 00 & 22 & 00 & 00 & 28 & 00 & 00 \\
\hline Proteus volgaris & 00 & 00 & 00 & 00 & 28 & 00 & 00 \\
\hline Pseudomonas aeruginosa & 00 & 00 & 00 & 00 & 28 & 00 & 00 \\
\hline Salmonella typhi & 17 & 27 & 20 & 21 & 32 & 00 & 00 \\
\hline Klebsiella pneumoniae & 19 & 25 & 21 & 25 & 40 & 00 & 00 \\
\hline Candida albicans & 00 & 21 & 00 & 00 & 00 & 24 & 00 \\
\hline Candida stllatoidae & 00 & 00 & 00 & 00 & 00 & 27 & 00 \\
\hline Candida tropicalis & 00 & 24 & 20 & 21 & 00 & 21 & 00 \\
\hline
\end{tabular}

Results: Mean of three trials \pm Standard error, $\mathrm{R} \rightarrow$ Resistance.

Sparflo $=$ Sparfloxacin (Bacteria Control): $10 \mu \mathrm{g} / \mathrm{ml}$

Flucona $=$ Fluconazole (Fungal control): $20 \mu \mathrm{g} / \mathrm{ml}$

The chloroform extract had the highest activity, followed by the ethyl acetate, then the methanol and lastly the petroleum ether. In (Table 2), the minimum inhibitory concentration (MIC) was $1.25 \mathrm{mg} / \mathrm{mL}$ on the average. MBC / MFC (Table 3 ) were carried out to check whether the bacteria and the fungi were killed or only their growth was inhibited with an average value of $2.25 \mathrm{mg} /$ $\mathrm{mL}$. MFC was found to be $5.00 \mathrm{mg} / \mathrm{ml}$ and was effective for chloroform, ethyl acetate and methanol. 
Antimalarial, Non Alkalodial Molecules of Nauclea Diderechi

Table 2: Minimum Inhibitory Concentration (MIC) of Petroleum ether, Chloroform, ethyl acetate and methanol extracts of the stem bark of $N$. diderichii on some fourteen micro-organisms

\begin{tabular}{|c|c|c|c|c|c|c|c|c|c|c|c|c|c|c|c|c|c|c|c|c|}
\hline \multirow{3}{*}{$\begin{array}{l}\text { Micro- } \\
\text { organ- } \\
\text { isms }\end{array}$} & \multicolumn{20}{|c|}{ Concentration $(\mathrm{mg} / \mathrm{mL})$} \\
\hline & \multicolumn{5}{|c|}{ Pet. Ether } & \multicolumn{5}{|c|}{ Chloroform } & \multicolumn{5}{|c|}{ Methanol } & \multicolumn{5}{|c|}{ Ethyl acetate } \\
\hline & 5.00 & 2.50 & 1.25 & 0.625 & 0.312 & 5.00 & 2.50 & 1.25 & 0.625 & 0.312 & 5.00 & 2.50 & 1.25 & 0.625 & 0.312 & 5.00 & 2.50 & 1.25 & 0.625 & 0.312 \\
\hline $\begin{array}{l}\text { Meth- } \\
\text { icillin } \\
\text { R.S.A }\end{array}$ & - & - & - & - & - & - & - & MIC & + & ++ & - & - & MIC & + & ++ & - & - & - & - & - \\
\hline $\begin{array}{l}\text { Staphy- } \\
\text { lococcus } \\
\text { aureus }\end{array}$ & MIC & + & + & ++ & +++ & - & - & MIC & ++ & +++ & - & - & MIC & + & ++ & - & MIC & + & ++ & ++ \\
\hline $\begin{array}{l}\text { Strepto- } \\
\text { coccus } \\
\text { pyro- } \\
\text { genes }\end{array}$ & - & - & - & - & - & - & - & - & - & - & - & - & - & - & - & - & - & - & - & - \\
\hline $\begin{array}{l}\text { Bacillus } \\
\text { sublilis }\end{array}$ & MIC & + & + & ++ & +++ & - & - & MIC & + & ++ & - & MIC & - & + & ++ & - & - & MIC & + & ++ \\
\hline $\begin{array}{l}\text { cory- } \\
\text { nebac- } \\
\text { terium } \\
\text { ulcereas }\end{array}$ & - & - & - & - & - & - & - & MIC & + & ++ & - & - & MIC & + & ++ & - & - & MIC & + & ++ \\
\hline $\begin{array}{l}\text { Esche- } \\
\text { richia } \\
\text { coli }\end{array}$ & - & MIC & + & ++ & +++ & - & - & MIC & + & ++ & - & - & MIC & + & ++ & - & - & MIC & + & ++ \\
\hline $\begin{array}{l}\text { Proteus } \\
\text { mira- } \\
\text { bilis }\end{array}$ & - & - & - & - & - & - & - & MIC & + & ++ & - & - & - & - & - & - & - & - & - & - \\
\hline $\begin{array}{l}\text { Proteus } \\
\text { volgaris }\end{array}$ & - & - & - & - & - & - & - & - & - & - & - & - & - & - & - & - & - & - & - & - \\
\hline $\begin{array}{l}\text { Pseudo- } \\
\text { monas } \\
\text { aerugi- } \\
\text { nosa }\end{array}$ & - & - & - & - & - & - & - & - & - & - & - & - & - & - & - & - & - & - & - & - \\
\hline $\begin{array}{l}\text { Salmo- } \\
\text { nella } \\
\text { typhi }\end{array}$ & - & - & MIC & + & ++ & - & - & MIC & + & ++ & - & - & MIC & + & ++ & - & - & MIC & + & ++ \\
\hline $\begin{array}{l}\text { Klebsel- } \\
\text { la pneu- } \\
\text { moniae }\end{array}$ & - & MIC & + & ++ & +++ & - & - & MIC & + & ++ & - & - & MIC & + & ++ & - & - & MIC & + & ++ \\
\hline $\begin{array}{c}\text { Candida } \\
\text { albicans }\end{array}$ & - & - & - & - & - & - & - & MIC & - & - & - & - & - & - & - & - & - & - & - & - \\
\hline $\begin{array}{l}\text { Candida } \\
\text { stllatoi- } \\
\text { dae }\end{array}$ & - & - & - & - & - & - & - & - & - & - & - & - & - & - & - & - & - & - & - & - \\
\hline $\begin{array}{l}\text { Candida } \\
\text { tropica- } \\
\text { lis }\end{array}$ & - & - & - & - & - & - & - & MIC & + & ++ & - & - & MIC & + & ++ & - & - & MIC & + & ++ \\
\hline
\end{tabular}

Key: - = no turbidity, (No growth), $+=$ turbidity (Light growth) $,++=($ Moderate growth $),+++=($ High growth $) \quad$ MIC $=$ Minimum inhibitory concentration 
Table 3: Minimum Bacteriocidal Concentration (MBC)/ Minimum Fungicidal Concentration (MFC) of Petroleum ether, Chloroform, ethyl acetate and methanol extracts of the stem bark of $N$. diderichii on some fourteen micro-organisms

\begin{tabular}{|c|c|c|c|c|c|c|c|c|c|c|c|c|c|c|c|c|c|c|c|c|}
\hline \multirow{3}{*}{$\begin{array}{l}\text { Micro- } \\
\text { organ- } \\
\text { isms }\end{array}$} & \multicolumn{20}{|c|}{ Concentration (mg/mL) } \\
\hline & \multicolumn{5}{|c|}{ Pet. Ether } & \multicolumn{5}{|c|}{ Chloroform } & \multicolumn{5}{|c|}{ Methanol } & \multicolumn{5}{|c|}{ Ethyl acetate } \\
\hline & 5.00 & 2.50 & 1.25 & 0.625 & 0.312 & 5.00 & 2.50 & 1.25 & 0.625 & 0.312 & 5.00 & 2.50 & 1.25 & 0.625 & 0.312 & 5.00 & 2.50 & 1.25 & 0.625 & 0.312 \\
\hline $\begin{array}{l}\text { Meth- } \\
\text { icillin } \\
\text { R.S.A }\end{array}$ & - & - & - & - & - & - & - & MIC & + & ++ & MIC & + & ++ & +++ & +++ & - & - & - & - & - \\
\hline $\begin{array}{l}\text { Staphy- } \\
\text { lococcus } \\
\text { aureus }\end{array}$ & MIC & + & ++ & +++ & ++++ & - & MIC & + & ++ & +++ & MIC & + & ++ & +++ & ++++ & MIC & + & ++ & +++ & ++++ \\
\hline $\begin{array}{l}\text { Strepto- } \\
\text { coccus } \\
\text { pyro- } \\
\text { genes }\end{array}$ & - & - & - & - & - & - & - & - & - & - & - & - & - & - & - & - & - & - & - & - \\
\hline $\begin{array}{l}\text { Bacillus } \\
\text { sublilis }\end{array}$ & MIC & + & ++ & +++ & ++++ & - & MIC & + & ++ & +++ & MIC & + & ++ & +++ & ++++ & MIC & + & ++ & +++ & ++++ \\
\hline $\begin{array}{l}\text { cory- } \\
\text { nebac- } \\
\text { terium } \\
\text { ulcereas }\end{array}$ & - & - & - & - & - & MIC & + & ++ & +++ & ++++ & MIC & + & ++ & +++ & ++++ & MIC & + & ++ & +++ & ++++ \\
\hline $\begin{array}{l}\text { Esche- } \\
\text { richia } \\
\text { coli }\end{array}$ & MIC & + & ++ & +++ & ++++ & - & MIC & + & ++ & +++ & MIC & + & ++ & +++ & ++++ & MIC & + & ++ & +++ & ++++ \\
\hline $\begin{array}{l}\text { Proteus } \\
\text { mirabilis }\end{array}$ & - & - & - & - & - & MIC & - & - & - & - & - & - & - & - & - & - & - & - & - & - \\
\hline $\begin{array}{l}\text { Proteus } \\
\text { volgaris }\end{array}$ & - & - & - & - & - & - & - & - & - & - & - & - & - & - & - & - & - & - & - & - \\
\hline $\begin{array}{l}\text { Pseudo- } \\
\text { monas } \\
\text { aerugi- } \\
\text { nosa }\end{array}$ & - & - & - & - & - & - & - & - & - & - & - & - & - & - & - & - & - & - & - & - \\
\hline $\begin{array}{l}\text { Salmo- } \\
\text { nella } \\
\text { typhi }\end{array}$ & MIC & + & ++ & +++ & ++++ & - & MIC & + & ++ & +++ & MIC & + & ++ & +++ & ++++ & MIC & + & ++ & +++ & ++++ \\
\hline $\begin{array}{l}\text { Klebsella } \\
\text { pneumo- } \\
\text { niae }\end{array}$ & MIC & + & ++ & +++ & ++++ & - & MIC & + & ++ & +++ & - & MIC & + & ++ & +++ & MIC & + & ++ & +++ & ++++ \\
\hline $\begin{array}{l}\text { Candida } \\
\text { albicans }\end{array}$ & - & - & - & - & - & MIC & - & - & - & - & - & - & - & - & - & - & - & - & - & - \\
\hline $\begin{array}{l}\text { Candida } \\
\text { stllatoi- } \\
\text { dae }\end{array}$ & - & - & - & - & - & - & - & - & - & - & - & - & - & - & - & - & - & - & - & - \\
\hline $\begin{array}{l}\text { Candida } \\
\text { tropica- } \\
\text { lis }\end{array}$ & - & - & - & - & - & MIC & + & ++ & +++ & ++++ & MIC & + & ++ & +++ & ++++ & MIC & + & ++ & +++ & ++++ \\
\hline
\end{tabular}

Key: - = no turbidity, (No growth), $+=$ turbidity $($ Scanty colonies growth $),++=($ Moderate growth $),+++=($ High growth $),++++=(\mathrm{v}$. heavy colonies growth) $\mathrm{MBC} / \mathrm{MFC}=$ Minimum Bactericidal Concentration / Minimum Fungicidal Concentration.

The alcoholic extract of $N$. diderichii showed anti-malarial activity against Plasmodium berghei berghei Nk65 to be $\geq 3800$ $\mathrm{mg} \mathrm{kg}^{-1}$ body weight of Swiss Albino mice. The suppressive test, curative effect, prophylactic effect and the survival periods in parasitaemia against chloroquine tolerant strain of Plasmodium berghei NK6 $5^{[18]}$ were highly encouraging. Anti-malaria,anti-bacterial and anti-fungal activities of the stem-bark of Nuclear diderichii may have been due to the synergetic effect of their chemical constituents or any single chemical compound may have had toxic effects. In various ancient literatures related to healthcare Clerodendrum have been reported for its anti-malarial activities because of the presence of a bitter principle. Studies with different parasites supported these ancient claims. These plants may be useful as a source for novel anti-plasmodial drugs/compounds from natural origin. 
Component identification: All findings with TLC, UV, IR and GC /GL mass confirmed with methyl and hydroxyl groupings as active components in the petroleum ether fraction of the $N$. diderichii as seen:

Structure 4

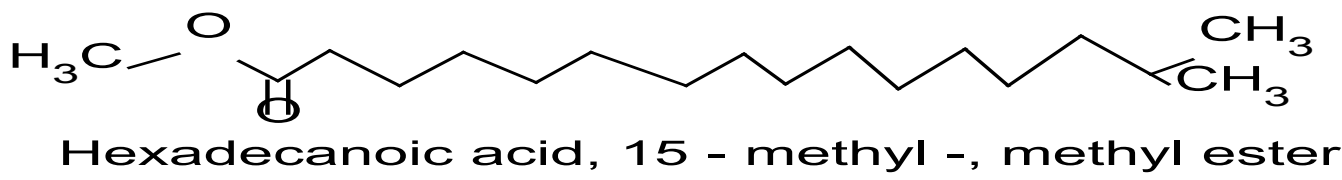

Structure7

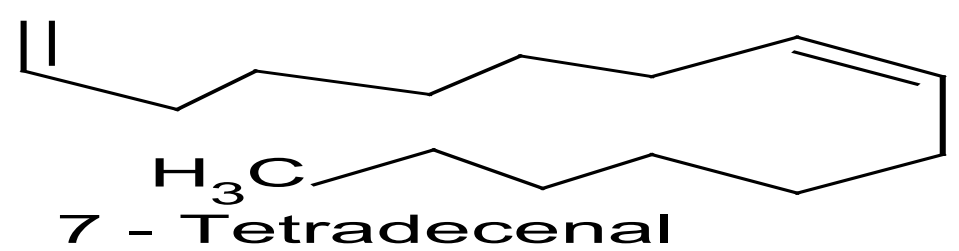

Structure $6(\mathrm{a} \& \mathrm{~b})$
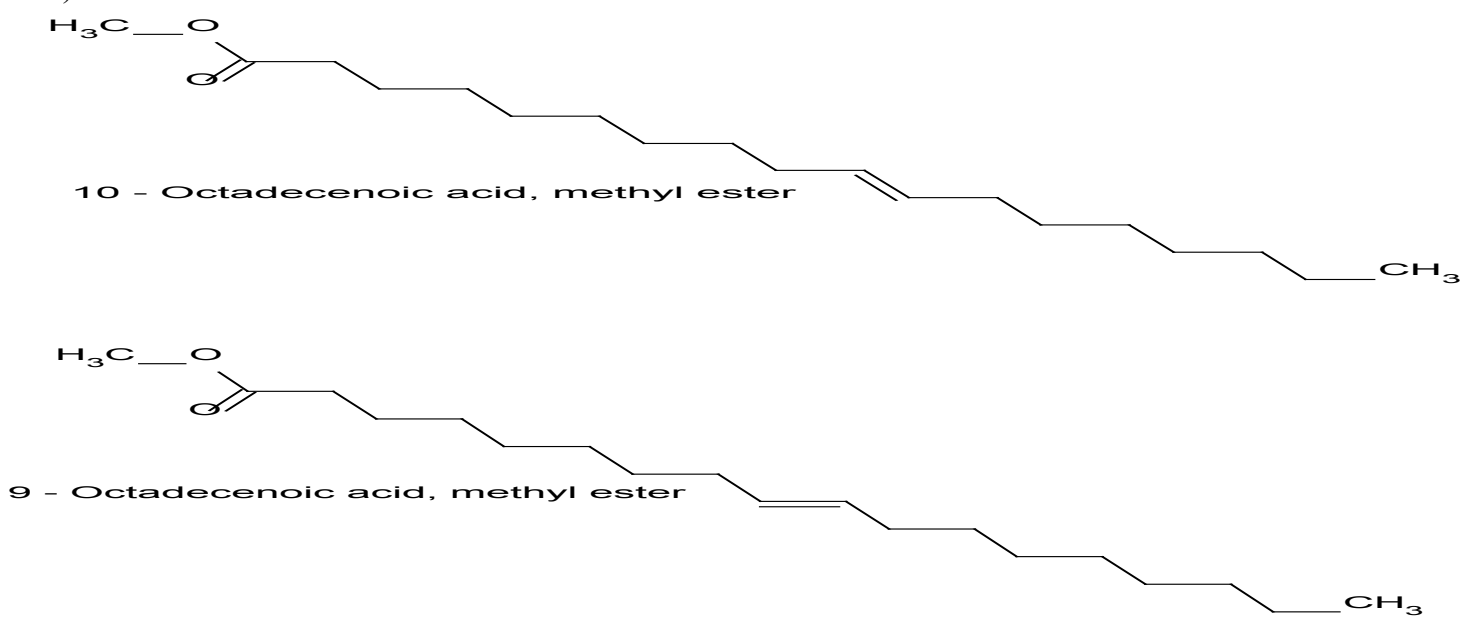

Structures $6 \mathrm{a}$ and $6 \mathrm{~b}$ are structural isomers with the difference only in the position of the ethylene moiety. One at position 9 and the other at position 10 .

\section{Conclusion}

From a natural chemist's viewpoint, all the structures that were extracted from the petroleum ether fraction of $N$. diderichii as the active components most have been partially/fully responsible for the activity in both microbes and the plasmodium berghei berghei Nk 65 and were non akaloidal or were all none alkaloids.

\section{Recommendation}

More work should be done on the plant so as to have good quantity of purified compounds for further anti-malaria activity. This will help to back-track and compare the activity of both the crude and the pure samples. Also, other solvent extracts should be elucidated for their active principles` activities on the microbes and the plasmodium species. 
Clinical and nutritional studies are recommended for the above indigenous plant so as to be able to advice locals in the various locations of the ill effects of the plant.

\section{References}

1. Harborne, J.B. Phytochemical Methods. (1992) Chapman and Hall Publications London 7-8.

2. Bhat, R.B., Eterjere, E.O, Oladipo, V.T. Ethno botanical studies from Central Nigeria. (1990) Economic Botany 44(3): 382-390.

3. Nwankwo, E.K., Kwaru, A., Ofulu, A., et al. Haematological changes in tuberculosis in Kano, Nigeria. (2005) J Medic Labor Sci 14(2): 35-39.

4. Emokpae, M.A., Nwokedi', E.E., Dutse, A.I. Biochemical changes in adult Nigerians with pulmonary tuberculosis in Kano-Nigeria. (2006) J Highland Medical Res 4(1): 15-21.

5. Nainwani, R., Singh, D., Gupta, A., et al. Anti-Inflammatory Activity of Various Fractions of Methanolic Extract of Punica granatum rind with its Phytochemical Evaluation. (2014) American J Drug Delivery and Therapeutics 1(1): 21-27.

6. Bakkour, Y., Makhoul, S., Nakat, H., et al. Chemical analysis of the essential oils from Punica granatum, Vitis vinifera and $\mathrm{Cu}-$ curbita maxima seeds growing in Lebanon by GC/MS. (2011) J Natural Products 4: 71-74.

7. Lamidi, M., Ollivier, E., Faure, R., et al. Quinovic acid glycosides from Nauclea diderichii. (1995) Planta Med 61(3): 280-281.

8. Vollekova, A., Kostalova, D., Sochorova, R. Isoquinoline Alkaloids from Mahonia aquifolium stem bark is active against Malassezia Spp.(2001) Folia Microbiol 46(2): 107-111.

9. Usman, H., Abdulrahman, F.I, Ladan, A.A. Phytochemical and Antimicrobial Evaluation of Tribulus terrestris L. (Zygophylaceae) Growing in Nigeria. (2007) Res J Biological Sci 2(3): 244-247.

10. Lorke, D. A new approach to acute toxicity testing. (1983) Arch Toxicol 54(4): 275-287.

11. Saidu, K., Onah, J., Orisadipe, A., et al. Anti-plasmodial analgesic and anti-inflammatory activities of aqueous extract of Erythrina senegalensis. (2000) J Ethnopharmacol 71(1-2): 275-280.

12. Adzu, B., Haruna, A. Studies on the use of Zizyphus spina-chriti against pain in rats and mice. (2007) African J Biotechnolo 6: 1317-1324.

13. Salawu, O.A, Chindo, B.A, Titanji, A.Y., et al. Acute and sub-acute toxicological evaluation of the methanolic stem bark extract of Crossopteryx febrifuga in rats. (2009) Afr J Pharmacy Pharmacol 3(12): 621-626.

14. Odeku, O.A., Adegoke, O.A., Majekodunmi, S.O. Formulation of the extract of the stem bark of Alstonia boonei as tablet dosage form. (2008) Trop J Pharma Res 7(2): 987- 994.

15. Titanji, V.P., Zofou, D., Ngemenya, M.N. The anti-malaria potential of medicinal plants used in the treatment of malaria in Cameroonian folk medicine. (2008) Afr J Tradit Compliment Altern Med 5(3): 302-321.

16. Idowu, O.A., Soniran, T., Ajana, O., et al. Ethno botanical survey of anti-malaria plants used in Ogun State Southwest Nigeria. (2010) Afr J Pharmacy Pharmacol 4(2): 55-60.

17. Deeni, Y.Y., Hussain, H.S. Screening for antimicrobial activity and for alkaloids of Nauclea latifolia. (1991) J Ethnopharmacol 35(1): 91-96.

18. Maje, I. M., Anuka, J.A., Hussaini, I. M., et al. Evaluation of the Anti-Malaria Activity of the Ethanolic leaves Extract of Paulinia pinnata Linn. (2007) Nig J Pharm Sci 6(2): 67-72.

Ommega Online Publishers

Journal Title: Journal of Pharmacy \& Pharmaceutics

Journal Short Name: J Pharm Pharmaceutics
Journal ISSN: 2377-1313

E-mail: pharmacoinformatics@ommegaonline.com

Website: www.ommegaonline.org 